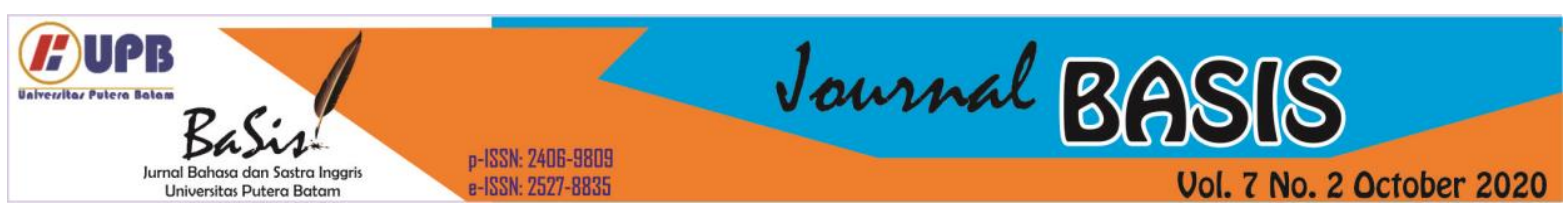

\title{
THE EFFECTIVENESS OF MAKING VIDEO BLOG (VLOG) TO MINIMIZE STUDENTS' ANXIETY IN PUBLIC SPEAKING ON DESCRIPTIVE TEXT MATERIAL
}

\author{
Dani Fitria Brilianti ${ }^{1}$ \\ Politeknik Harapan Bersama, Tegal, Indonesia \\ e-mail: hello.fiabrilianti@gmail.com ${ }^{1}$ \\ Arief Zul Fauzi ${ }^{2}$ \\ Politeknik Harapan Bersama, Tegal, Indonesia \\ e-mail: mail.ariefzf@gmail.com²
}

\begin{abstract}
The ability in to speak English in the public place being a scourge for students due to minimize the anxiety because of lack of speaking practice in their life, so that an effective media is needed to decrease the students' anxiety in speaking by making video blog (VLOG) . The aims of this study are to minimize students' anxiety in public speaking that focus on descriptive text teaching materials, and to improve students' speaking skills in the context of description through VLOG media. The subjects in this study is the student of DIII Computer Engineering at the Polytechnic of Harapan Bersama Tegal with a qualitative descriptive research approach by using the Classroom Action Research (CAR) method in two cycles, each of the cycle consists of four stages of planning, implementation, observation, and reflection. The data collection method in this study is to use a questionnaire, interview, observation, and reflection in accordance with the Action Research guidelines. The finding showed that the average of pre test score was only 52.5, after treating by video blog it was improved to 74.5 in cycle 1 , then it improved more in cycle 2 and reached 87.3. So, it improved 34.8 point from pre test to the post test. In line with the data, designing video blog is effective to minimize students' anxiety in teaching spoken descriptive test and it works to improve the students speaking skill. Moreover, students also get their own motivation to speak confidently in the public place. Some aspects that improved are fluency, pronunciation, vocabulary items and content. As the final result, it can be inferred that making video blog minimize students' anxiety in speaking and it improves students' speaking performance.
\end{abstract}

Keywords: Video Blog (VLOG), anxiety, public speaking, descriptive text

\section{INTRODUCTION}

Facing the industrial era 4.0, students now can not only be demanded to be able to master material related to film that can be supported also with soft skills and abilities that support qualified to be able to compete with the international community. Mastery of foreign languages, especially English becomes very important because its use has been adapted to all elements of the field, economic, social, cultural, political, health, to law and defences. Almost every second, students who have the vision and mission to be able to enter the global competition are expected to be 
able to help convey ideas or support their knowledge in English.

Unfortunately, the position of English in Indonesia is only limited to a language that is often ruled out by many people, including students who involve space and media to hone English language skills. Excessive speaking skills and refute speaking skills. People become very anxious about the various mistakes made, challenging to be laughed at by others, even opposing their own abilities that are not necessarily the audience or the listener has the ability to speak far better than the speaker. In line with Horwitz (1986: 31) which states that opposing speakers of English is caused by three aspects including difficulties in communication, difficulties in evaluating the negative, and also other general issues that occur when responded.

Back to the nature of 4.0 industrial revolution, students in Indonesia must challenge themselves in globalization. They are not only competing with their local people from inside this country but also other people outside of the country that come from all the sides of this world. The competition is not by sending students to joining in a competition in particular country. It is involving the new 4.0 revolution technology such as social media and broadcaster media. There is so much way to join the competition worldwide using the 4.0 technology such as emailing, online drafting, online group discussion, and the common popular nowadays is vlogging (video and blogging).

As stated by Mogallapu (2011: 6) a video blog is a modification of blogging activity that use video as the media in taking and publishing. Nowadays, vlog becomes very popular in millennial influencer to get popularity, money, or even for being viral in social media. Furthermore, people around the world are being familiar with vlog because it is easy to assess and make only by using any kind of gadget that we have (Deanova, 2004). As a fact, making vlog is very easy and challenging for people to show-off themselves' ability without meet directly with the particular people. This trend has been starting popularly around 2010.

Many popular educators are also making their own vlog and uploading to Instagram and YouTube channel as the medium of sharing especially in teaching speaking. According to this situation, it is necessary to find out media that can be accepted by the students easily to avoid their anxiety in learning and practicing speaking. In addition, from those kind of needs in teaching and learning process, researchers think that video blog is one of the best idea in developing media especially for teaching speaking. Video blog provides huge and holistic of language content that can be exploited in teaching speaking, it also motivate the audience for being active and creative in building language.

Some studies have been investigated by several researchers that focused on anxiety of students' speaking skills and using Vlog as the solver medium. Safitri and Khoiriyah (2017: 240) discussed about the students' perception on the use of English vlog to increase their speaking skill and to find out about the students' strategy to improve the students' speaking skill by using English video blog (VLOG). There were five students of English Education Department of Universitas Islam Indonesia who learnt listening and speaking subject. The authors applied a purposeful sampling technique to get samples. The type of research was qualitative approach. This study concerned to the students' perception in using English vlog media and the students' strategy in using it. The data 
collected from the students' interview, observation, and documents. The result of the study shows that the learning and teaching process that use English vlog media is significantly improve the students' speaking skill.

The study from Evyanto (2018:65) explained about the effectiveness of audio visual media in teaching English speaking. It implemented in the VIII's grade of some junior high school students of Batam's state junior high schools. The aim of this study was to investigate the implication of audio visual media used in teaching speaking English. From the data investigated, all the students agreed that audio visual media helped the teaching and learning process. The learning and teaching process also done effectively and efficiently if the teacher used audio visual as the media to help students understood the material given.

Other findings were carried out by Wulandari (2019: 111). The researcher investigated whether Instagram Vlog contributed to the improvement of EFL's speaking ability or not. It also examined learners' perceptions of Instagram Vlog that is applied in speaking class. To determine the impact of the Instagram Vlog on EFL learners' speaking ability, pre- and post-tests were administered to measure the improvement. The results of the research indicated that the implementation of Instagram Vlog into a basic-level speaking class improved the learners' speaking proficiency in terms of pronunciation, fluency, vocabulary, syntax, and general use of the target language. The analysis of the questionnaire demonstrated that the utilization of Instagram vlog contributed to EFL learners' speaking skill on enhancing fluency, acquiring vocabulary items, and boosting confidence and motivation.
Sari (2017: 38) in her research entitled "Using Vlog in the YouTube Channel as a Means to Improve Students' Motivation and Confidence to Speak English in Intermediate 1 Level of LB-LIA Jambi" found that almost students are hard to speak English despite the fact that they have the basic knowledge of the language due to the lack of motivation and confidence. As the technology advances, teachers must be willing to take advantage of the potential channels provided by it. Her study was aimed to improve the students' confidence and motivation in speaking English by using video blog (VLOG) from the YouTube Channel as the way to identify about what kind of the element that give the best improvement of students; motivation and confidence. The data were obtained through classroom observation, questionnaires, and interviews. In terms of findings, this study revealed that the use of Vlog that served by YouTube Channel improved the students' motivation and confidence. The data also suggested that some of the students were feel motivated and confident in speaking English because they were given time to think widely of what they wanted to share. Therefore, teacher also suggested to collaborate any kind of technology to the classroom so they can feel convenient to speak more.

Related to the research of Maulidah (2017:12) that study about vlog as the media to improve students; speaking ability born some facts. Video blog improves the students' speaking ability significantly. It boost the students' motivation by bringing fun atmosphere in the learning and teaching process. Moreover, vlog gives good influence in speaking skill especially for pronunciation. In the other hands, the students get many chances to develop their autonomous learning that directly 
bring the students' good progress in learning speaking. The further discussion, vlog becomes a media that provide a practical concept that implemented brilliantly.

Mogallapu (2011: 6) analyzed the social network structure of friends and subscribers of the 187 video bloggers on YouTube and calculated the social network measures. This thesis compares the results to the structure described by Warmbrot et al. in 2007 and explains the reasons for the distinctions. The number of video bloggers has increased enormously, and the form of their interactions has changed. As a result, the video blogger social network has evolved from a core/periphery structure to one that is centralized. This indicates that the video blogger community on YouTube presently revolves around few central people in the network.

Another anxiety related research has been done by Indrianty (2016: 28). She investigated the students' anxiety in speaking English that is assessed in Hotel and Tourism Collage Bandung. This study identified the types of anxiety and sources of students' anxiety. The study revealed two findings related to the research questions. First, there are two types of anxiety were evidenced i.e. the trait anxiety and situational anxiety. Second, the students' anxiety in English caused by three factors i.e. communication apprehension, the test, and fear. Moreover, the interview data revealed, students' lac of vocabulary and lack of preparation have also contributed to the students' anxiety in speaking. There finding suggest that as the teacher should give high motivation to the students and think about an effective media to solve the problem.

As the previous study explained, video blog is one of the alternative media to enhance students' speaking and give them a motivation for being confidence in public speaking. It is expected that every students can get some ideas in developing the theme of speaking content after watching some video blogs, so that they can make their own personal English video blog. They also can improve their pronunciation as well as a native speaker, improving the vocabulary items, and make good sentences with an appropriate grammar.

This study focused on the students' learning process and the aims of this study are firstly to investigate the effectiveness of video blog to minimize the anxiety of students' public speaking and secondly, to find out to what extend the use of video blog can improve students' speaking abilities in descriptive text.

\section{LITERATURE REVIEW \\ 2.1. Speaking Skill}

Speaking skill is one of the four basic skills of language that must be mastered by the foreign speakers who learning English language. Naturally, humans can produce many words every day to represent their ideas as the part of communication. Speaking skills are also defined as one of the skill of foreign speakers to represent their ideas from their mother tongue/native language into the target language. Thronburry (2006: 4) states that the essence of speaking is a process of structure language structure is changed from written to the spoken context. In the process of teaching and learning English, the definition of speaking skill is the ability of language practicing or developing continuously and independently to express people's idea, opinion, feeling, belief, and thought in a particular language.

Speaking skill is one of the English skill that get special attention because it does not only require the linguistic components such as vocabulary items and grammar. However, independence 
and self-confidence are needed to support people's speaking skill performance. In the speaking skill, Thronburry (2005: 28) states that the supporting thing that should be developed and sharpened include vocabulary items, sentence structures that need to be improved, fear and anxiety about mistakes made as much as possible should be minimized, on the other hand, independent learning should be encourage so that the learners are always being independent and being confident to every achievement that they have.

\subsection{Anxiety}

Anxiety is a popular issue that is often brought up in language learning especially in learning speaking skill. Horwitz et.al (1986: 31) states that the anxiety that often occurs in language learning is a part of complex misconception about self-confidence, the level of trust in something, feeling, behavior related to the circumstance or environment, so that it greatly affect the process of language learning. He also said that due to the excessive level of anxiety, it will damage learning's academic achievement especially in the speaking aspect. It happen because speaking skill requires high level of selfconfidence to produce proper language. For some people who have lack of selfconfidence, speaking is very harmful, that is a serious case which hinder their language learning process. This is also explained by Horwitz et.at (1986: 31-32) that every foreign learner that have their high anxiety in speaking will directly lose their ideas or points of discussion topic that they will share to their partner. This is due to the limited practice space, lack of comfort atmosphere in speaking especially in public speaking.

In the other hand, Guiora in Zhipping (2013: 3) confirmed that leaning language becomes a painful thing for some people, this is due to direct facial contact with their teacher or lecturer in the classroom. The existence of innovative methods or media can reduce the intensity of direct face contact with the language mentor is expected to reduce excessive anxiety towards learners in mastering speaking skill.

The existence of innovative methods or media that can reduce the intensity of direct face contact with language mentors is expected to reduce excessive anxiety towards learners in mastering speaking skills.

\subsection{Video Blog (VLOG)}

Video Blog (VLOG) is a form of blogging activity by using video with certain themes that is packed in journalistic documentation recorded by using various devices such as cell phone with camera or digital camera equipped with a microphone assisted by a tripod (Mogallapu, 2015: 5). Vlog activity in Indonesia is relatively new and it targeting the youth segment. This activity has a lot of content that can be designed to any interests. An easy, effective, and efficient process of vlogging activity is the newest way to communicate with people around the world, though, vlog is a one-way type of communication. However, this media is considered very powerful to describe something to share many various type of information needed.

Vlog is an applied technology that is appropriate to be applied in the learning and teaching process, especially in learning speaking skill. Vlog serves a big space to guide and teach the learners in learning speaking. In this case, learner is able to compose any content of speaking to speak freely without intimidation or fear of the various language error that maybe caused. Through vlog, learner is also expected to be able to learn spoken English independently without always depend on his/her teacher/lecturer. 
Learner can doing vlog activity anywhere, anytime and upload it in to any social media to share to the public.

\section{RESEARCH METHOD}

In conducting this research, a qualitative approach by using an action research method was applied to the classroom because it was appropriate to the aim of this study which was used to minimize the anxiety in the public speaking performance so that the students would get their speaking improvement in descriptive text by using VLOG. An action research related to the reflective practice to identify some issues that faced by the participants in order to discus and find the best solution of the problems found, then carry the improvements to the in practice (Burns: 2010). Related to Kemmis, S., Mc Taggart, R., \& Nixon, R. (2014: 11) classroom action research is a typically method that use of qualitative, interpretive modes of enquiry also the data collection that conducted by the researchers with a view to the researchers for making judgments about the way to improve their practices.

Classroom action research is one of the research designs that could overcome some problems that faced by the researchers in teaching and learning process by using several ways and it happened for twice or mode depend on the improvement that the researchers' wanted. It has cycling process which involves some phases of planning a change, acting the process, observing the process and the treatment, and reflecting on the processes happened (Kemmis, S., Mc Taggart, R., \& Nixon, R., 2014: 18). That cycle would be the first cycle that has a result to determine the needs that should be improved in the following cycle till the problem solved.
Figure 1. The Classroom Action Research Cycles based on Kemmis, S., Mc Taggart, R., \& Nixon, R., (2014: 18)

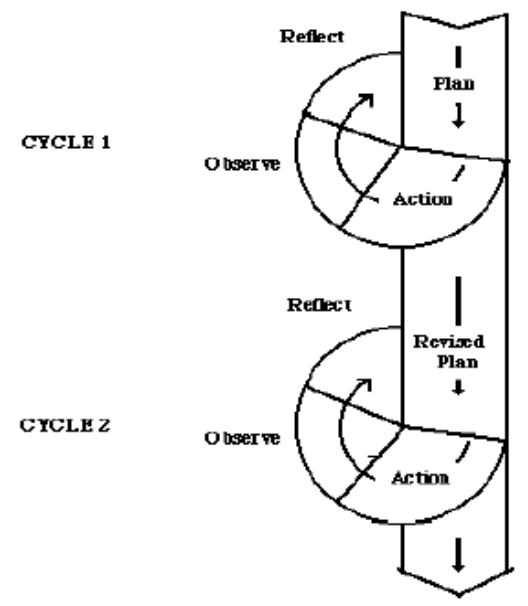

The figures clearly figure out the major steps of planning, action, observation, and reflection in each of the cycle. Planning stage focused on identifying of the problem faced that was anxiety in public speaking, then found the media, in this case we focused on the video blog to solve the problem, designed teaching and learning instruments, prepared the collaborators, and designed tests. In action stage focused on finding the pre-test, treatment: script process, practicing, presenting (cycle 1), shooting, and screening (cycle 2). The next stage, observing, which focused on the data collection, recording the learning and teaching activity, interview, and filling the questionnaire. The last stage is reflection, which talked about making conclusion and feedback.

This study was implemented in the second semester of Computer Engineering Department of Politeknik Harapan Bersama that consist of 32 students. So, in this study, the performance test focused on the group performance test. In collecting the data, the techniques which were used were direct observation, and measurement technique. The observation used the observation checklist, field note in 
identifying the learning and teaching process, besides that there were performance tests, questionnaire and interview. The observation checklist was used to collect the data about students' activity and interaction in the each meeting of teaching and learning process by using video blog in the classroom. It focused on the response of the students in treatment session, their gesture in speaking, and the aspect of language in speaking test. In the other hand, filled note was used to write any data that were not mentioned in the observation checklist, also to identify some aspects reflected during learning and teaching process. Next is the performance test was the form of the result test of the students speaking performance for describing speaking ability, grouping score, mean score, and average score that assessed after the treatment that given by the researchers. This test was taken in the end of each of the cycles. Actually, in the first cycle, students were asked to show directly their project in making their speaking performing to describe something in front of the classroom, after the reflection in the cycle 1 and continued to the cycle 2, students were asked to record and make their own video blog as the performance test to get more result of the treatment that have done.

Validity of the data was very necessary, so to confirm the validity of research data, therefore, the triangulation is used. Questionnaire was also administered to the students in the end of the cycle. That was very important to have their feedback or just to confirm for any data of the students' and their feeling. Furthermore, there are some students were selected to be interviewed that held in the end of the cycle 2 test to have students' confirmation about their feeling and get their feedback in the process of learning and performing test.

\section{RESULT AND DISCUSSION}

\subsubsection{Results}

Speaking became a serious problem for almost students of computer engineering in learning English, so in this case, researcher conducted Classroom Action Research (CAR) in two cycles. Before doing the first cycle, pre-test was assessed to the students as the basic data for their speaking skill. After doing the pre-test, cycle 1 and cycle 2 test were also conducted orally. On the other hand, the time for doing the treatment of English subject was $2 \times 100$ minutes in every cycles. The result of every cycles showed some improvements of the speaking skill of the students. The result of each test in this research was shown in this table below:

Table 1. The Improvement of Speaking Skill of Students

\begin{tabular}{|c|c|c|c|c|c|c|c|}
\hline \multirow[t]{2}{*}{ No. } & \multirow[t]{2}{*}{$\begin{array}{c}\text { Aspects } \\
\text { of } \\
\text { Language }\end{array}$} & \multirow[t]{2}{*}{$\begin{array}{c}\text { Pre } \\
\text { Tes } \\
\text { t }\end{array}$} & \multicolumn{2}{|c|}{$\begin{array}{c}\text { Cycle } \\
\text { (Averag } \\
\text { e Scores) }\end{array}$} & \multicolumn{3}{|c|}{ Improvement } \\
\hline & & & 1 & 2 & $\begin{array}{l}\text { Pre } \\
\text { Test }\end{array}$ & $\begin{array}{c}\text { Cycle } \\
1\end{array}$ & $\begin{array}{c}\text { Cycle } \\
2\end{array}$ \\
\hline 1. & Content & 60 & 80 & 93 & 20 & 13 & 33 \\
\hline 2. & $\begin{array}{c}\text { Fluenc } \\
y\end{array}$ & 45 & 73 & 88 & 28 & 15 & 43 \\
\hline 3. & $\begin{array}{l}\text { Pronun } \\
\text { ciation }\end{array}$ & 50 & 70 & 80 & 20 & 10 & 30 \\
\hline 4. & $\begin{array}{c}\text { Vocabu } \\
\text { lary }\end{array}$ & 55 & 75 & 88 & 20 & 13 & 33 \\
\hline \multicolumn{2}{|c|}{$\begin{array}{c}\text { Average } \\
\text { (Mean) }\end{array}$} & 52.5 & $\begin{array}{l}74 \\
.5\end{array}$ & 87.3 & 22 & 12.8 & 34.8 \\
\hline
\end{tabular}

Moreover, the diagram chart of the table was:

Diagram 1. The Chart of Students' Speaking Improvement

\section{Students' Speaking Improvement}

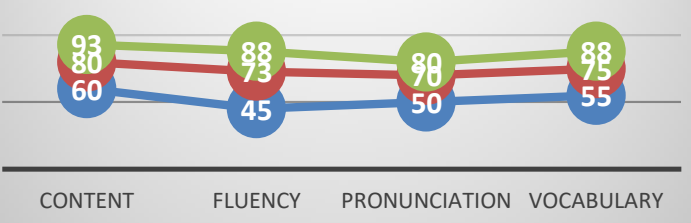

$\longrightarrow$ Pre Test $\leadsto$ Cycle $1 \longrightarrow$ Cycle 2 
This result was also supported by the result of the questionnaire given to the students in the end of cycle 2 with the result was almost $98 \%$ of the students enjoy and love the activity on the classroom. They said that by making their own video blog was very helpful to minimize their anxiety in speaking. They really enjoy to have their own real life in learning English without intimidation. In addition, researcher also had an interview to some students, in this case three students, as the representative and all of them agreed that making personal video blog was really interesting and helpful.

In the first cycle, the researchers and the collaborator presented the materials and show the media as the alternative way to minimize students' anxiety in speaking skill. Furthermore, the researcher observed the class by taking the video, notes, and doing the observation checklist. The procedure of doing this research was based on the lesson plan that were divided into three steps of learning, they were pre-activity, main activity, and post activity.

The treatment was started from the pre-activity, there were two researchers as the lecturers, and the first lecturer started the teaching process by greeting and praying. After that, she checked to the students; attendance list. There were 32 students joined to the class on that day. Next, she told the students about the indicator, material, and goal of the study. Before jumped up to the main activity, she asked to the students to describe something in front of the classroom as the warming up and after very long time to wait and motivate them to be brave and not to be panic, there was a student as a volunteer who describing her classroom by using simple sentences. After her performance, the lecturer asked all students to give their applause to her as the good feedback and appreciation.
In the beginning, the lecturer felt hard to motivate students to be relax when they had to perform something in English, almost all of the students felt and worried when they had to speak in English.

As the main activity, the lecturer brought her previous case to the class about describing something by making personal video blog. She discussed about what the video blog is, some examples of video blog that use English as the language, show some benefits and the differences between conventional method and video blog, also motivated them for being active in speaking English without any worries. On the next activity, the second lecturer gave the simple material about descriptive text such as the language features and generic structure of the text. After that he asked to the class to make groups that consist of 4-5 students based on the pretest result scores. The best top five students became the leader of the group to make a simple spoken descriptive text with the theme personal computer vs laptop and design it as the video blog performance, he gave 25 minutes to make their own descriptive vlog. All of the group discussed with their own member, surprisingly they were very active and responsive. While the students were busy to their discussion, both of the lecturers helped the students if they faced any troubles. After 25 minutes left, the lecturers asked one or two groups to present their performance in front of the classroom. It was different with the previous activity, in this case, a volunteer group presented their performance in front of the classroom with more passion in self-confidence. Two students as the representative of the first group showed their performance like a content creator in describing personal computer and laptop, however they were still shy and lost their words in 
the beginning of their performance. After that, the teachers gave their feedback about their speaking performance as well. The last, the lecturers asked to the students about the lesson and activity of today. Some of the students answered to the lecturers and showed their respect better than before. Then, the class was closed.

The result of the first cycle activity taken by the researchers through the direct observation, performance test, questionnaire and some interviews. Based on the lecturers and collaborator's observation when the lecturers gave the explanation about the materials while played and showed the video blog, most of the students paid their attention to the lecturers and the video given, about $90 \%$ of the students focused to the video both of the first and the second meeting on the first cycle. It showed that there was improvement in their passion for learning speaking, they also made some discussion with their partner to avoid the anxiety while speaking English. In some moments noted that some of the students practice in speaking English freely without looking up to the dictionary as the way to make them confidence to speak in English. However, still there were students looked passive and quite because of some of them were shy and worry to say something.

The speaking performance test was conducted at the end of the second meeting of the cycle 1 . The result showed that their speaking performance was improved especially in the fluency and pronunciation. It indicated that some of the students felt enjoy in speaking English, no more feeling in intimidation of scoring system, so they could speak English fluently. However, it should be improved more because still not too significant. The average score of the pretest was 52.5, and in the cycle 1 performing test was 74.5.
After doing cycle 1, there were aspects that should be improved more by the researchers. Several points that have to be improved were group discussion should be followed only 2-3 students in each groups to minimize passive participation of the students based on the cycle 1 result test, so the best top 10 on the cycle test were being the leader of their group. Secondly, the video vlog as the media to encourage the students' motivation in speaking English should be only focused in American Accent / American English to minimize students' confusion in pronunciation. In this cycle also focused on vocabulary items and how to explore the content of the themes given to make their text out of the box. The last but not least, the most significant aspect that made the cycle 1 and cycle 2 difference was the students have to make their own video blog and uploaded to their personal YouTube channel as the performance test on the cycle 2 .

In the cycle two, the teaching method was more flexible than before. Students sit on the U-shape so, they could discuss and practice freely. They also practiced the speaking task outside the classroom so they got the feeling, and explored more objects outside. The result of the activity in the cycle two also taken by the lecturers, collaborator, performance test, questionnaire and interview that conducted in the end of the cycle 2 . Based on the observation of the lecturers and the collaborator actually found $98 \%$ students really focused to the video blog shown both at the first and the second meeting of cycle 2. The situation of the class was also more active and attractive, they could manage their selves for being serious in paying attention and relax in practicing speaking. Almost of them felt enjoy the class without any boundaries and intimidation, they could speak freely like 
a daily use conversation even they had to speak in the formal situation. This finding showed a significant improvement result compared with the pre-test and the cycle 2 test result, the performance test average result on the cycle 2 was 87.3.

\subsection{Discussion}

From the table and the chart clearly showed there were improvements in every test that was conducted. The average score in pre-test was only 52.5. It indicated students were only get low score, under the score standard that was 71. Almost of the students had problems in every aspects of language of speaking skill. In general, from the pre-test, students had serious problem in fluency and pronunciation. This case happened because of some of them never doing practice in speaking, they also felt fear to share their ideas in speaking.

In this case, the use of video blog in teaching spoken descriptive to was designed to minimize students' anxiety in speaking, so if they felt enjoy and relax in speaking they would have good performance in speaking too. This media also helped students to enrich their fluency, pronunciation, content, and vocabulary. After watching and learning from the video blog that presented by the lecturers, students got some ideas to speak up, beside that from the group discussion directly gave the opportunity to all member of the group to share their idea orally to improve their speaking skill. So, after treating by using video blog, the students' anxiety while they were speaking was getting better. There was a significant improvement in the end of the cycle 2 performance test, that was 87.5 as the average score in cycle 2 result test, and the students' achievement to speak English from the pre-test to the cycle 2 performance test was high.

\section{CONCLUSION}

According to the result of the data and discussion in this study, it could be concluded that designing video blog is effective to minimize students' anxiety in teaching spoken descriptive test and it works to improve the students speaking skill. It was proven by the result of the students' achievement score and researcher's observation while teaching and learning process. Teaching students by using video blog is very useful to improve students' ability in speaking, the nature of the daily language that used on the video which give the clear detail of object, picture, audio, gesture, mimic at the same time is really help the students learn their vocabulary, pronunciation, make them fluent in speaking, and help them to find out ideas. Students also feel comfortable and confident when can learn English from the real native speaker even that is only from the video. Watching video blog as the model of learning can help them to practice their own speaking in the classroom and outside, so they flexible to access or watch many videos related to the themes that they want to explore and it can improve their pronunciation and fluency in speaking.

Video blog is only one of the alternative media can be used in learning and teaching process especially in teaching speaking. Actually there are many media that can be used as the media that can be used to improve students' achievement in speaking but we know the result of the speaking performance test shows the good improvement aster treating by video blog, so there are some suggestions proposed to the English lecturer, university/institution, and the further researchers. The first is video blog is an appropriate media in teaching speaking for descriptive text. So, that's why lecturer should use it as the alternative 
media to minimize students' anxiety and motivate them to speak English as natural as they can. Lecturer also can motivate students to make their own video blog as the way to practice in learning speaking. Secondly for the institution, university or institution is expected to support their lecturers in exploring technology by providing good free wi-fi connection. Next, for the further researchers hopefully they can explore to many skills of English for example in listening, reading, or even for writing and can be used as the one of references. Finally, we hope that the result of this research will be useful for the readers, wish all the readers will have more data and information about video blog in teaching speaking for descriptive text.

\section{REFERENCES}

Anderson, Mark and Anderson, Kathy. 1997. Test Type in English 2. South Yarra: Maccmillan Australia Pty Ltd.

Balley, Katheen M. 2005. Practical English Language Teaching: Speaking. Singapore: McGraw_Hill ELT.

Brilianti, DF.,. 2017. The Effectiveness of Using Flash Animation as an Alternative Media in Teaching Spoken Report of Computer Engineering Students at Polytechnic Harapan Bersama Tegal. Concept. Volume 10 (1). Cirebon: UMC Press.

Brown, HD. 1993. Understanding Research in Second Language Learning: A Teacher's Guide to Static and Research Design. Cambridge University Press.

Evyanto, Winda. 2018. Efektifitas Media Audio Visual dalam Meningkatkan Keterampilan Berbicara Bahasa Inggris Siswa. Basis Journal. Volume 4 (1). Batam: UPB Press.

Gerlach, Vernon S. 1971. Teaching and Media. New Jersey: Hall Inc..
Horwitz, E. K., et.al. 1986. Foreign Language Classroom Anxiety. The Modern Language Journal. 70(2). 125-132.

Kirschner, C. (2012). What on earth is vlogging?. MNN HOLDINGS, LLC, 8, 12.

Liu, Yu-Ling. 2014. The Integration of Technology and Aesthetics when Student Teachers Undertake Blended Learning in Adolescent Psychology: An Interdisciplinary Approach. Academic Journal. Vol 9 (20). Pp. 1002-1012.

Indrianty, Septy. 2016. Students' Axienty in Speaking English. ELTIN Journal. Volume IV(I).

Mark, A. and Kathy Anderson. Text Types in English 1. MacMillan.

Maulidah, I. .2017. Vlog: the Mean to Improve Students' Speaking Ability. In International Conference on English Language Teaching (ICONELT 2017). Atlantis Press.

Mogallapu, Anusha. 2011. Social Network Analysis of the Video Bloggers' Community in Youtube. Dissertation. Missoury University.

Nunan. D. 2000. Language Teaching Methodology. Pearson Edu. Limited.

Safitri, N. S. A., \& Khoiriyah, I. (2017, July). Students' Perceptions on the Use of English Vlog (Video Blog) to Enhance Speaking Skill. In ASEAN/Asian Academic Society International Conference Proceeding Series.

Sari, P. (2017). Using Vlog in the Youtube Channel as a Means To Improve Students' Motivation And Confidence to Speak English in Intermediate 1 Level of LB-LIA Jambi. International Journal of Language Teaching and Education, 1(1), 38-44.

T. Danova, "Business Insider," Tech Insider, 5 January 2004. [Online]. Available: 
http://www.businessinsider.com/m obile-videostatistics-andgrowth201312?IR=T\&r=US\&IR= T. [Accessed 14 May 2020].

Thornbury, Scott. 2005. How to Teach Speaking. Longman.

Wulandari, M. (2019). Improving Efl Learners'speaking Proficiency Through Instagram Vlog. LLT
Journal: A Journal on Language and Language Teaching, 22(1), 111-125.

Zhiping, Dhiao., et. Al. 2013. Axienty of Speaking English in Class Among International Students in Malaysian University. Vol $1(11)$. 